\title{
The Burden of Chronic Obstructive Pulmonary Disease in Cardiovascular Diseases: A Non-Western Perspective
}

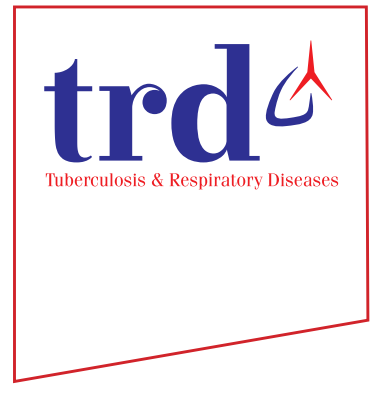

\author{
Kartik Deshmukh, M.B.B.S. ${ }^{1}{ }^{(\mathbb{D})}$ and Arjun Khanna, M.D., D.M. ${ }^{2}$ \\ ${ }^{1}$ Fuqua School of Business, Duke University, Durham, NC, USA; ${ }^{2}$ Department of Pulmonary Medicine, Yashoda Hospital, Delhi, \\ India
}

Our previous article summarized the prevalence, complications, and implications of managing chronic obstructive pulmonary disease (COPD) in cardiovascular disorders (CVD) ${ }^{1}$. A critical limitation of the review was the predominance of cardiovascular disease and comorbid COPD data from the United States and Europe. This was mainly due to greater cardiovascular disease registries in the United States and Europe vs. the rest of the world. It becomes necessary to highlight a "non-Western" perspective for the prevalence of COPD in CVD at the regional level for guiding clinical decisions that will optimize resources and improve patients' quality of life.

We reviewed the literature for the studies, which captured the status of comorbid COPD in cardiac patients, and were conducted in Asia, the Middle East, Africa, and South America conducted between 1981 to May 2020. The prevalence of COPD in heart failure (HF) and COPD in ischemic heart disease (IHD) and atrial fibrillation (AF) across different regions have been summarized in Tables 1 and 2, respectively.

One of the critical limitations of the evidence presented above has been the use of history/physical examination to diagnose COPD in cardiovascular disease patients. The prevalence varies from $3 \%$ to $30 \%$ in HF; the differences in prevalence can be accounted by reliance on clinical examination/history/medical records, instead of lung function tests,

Address for correspondence: Kartik Deshmukh, M.B.B.S.

Fuqua School of Business, Duke University, Fuqua Drive, Durham, NC 27708, USA

Phone: 1-919-3089590, Fax: 1-919-3089590

E-mail: Kartik.deshmukh@duke.edu, Deshmukh.kartik333@gmail.com Received: Nov. 29, 2020

Revised: Jan. 21, 2021

Accepted: Feb. 16, 2021

Published online: Feb. 17, 2021

(9) It is identical to the Creative Commons Attribution Non-Commercial License (http://creativecommons.org/licenses/by-nc/4.0/). to make a diagnosis. We now know that use of history/physical examination/medication can lead to both over-diagnosis and under-diagnosis of COPD. However, in the regions under consideration, it is prudent to assume that under-diagnosis of COPD is much more common than over-diagnosis, leading to poor health outcomes and increased healthcare costs in the long run. Another factor to look at is the general prevalence of COPD in the country where studies were conducted. One would expect at-least equal or ideally higher prevalence of COPD in HF/AF/IHD versus general population (Table 1) because of the common risk factors involved in pathogenesis of both COPD and heart disease. In certain studies such as the one by Barretto et al. ${ }^{2}$, the drastic difference in study reported COPD prevalence and general COPD prevalence might be due to recruiting bias and/or improper evaluation of airflow limitation leading to under-diagnosis of COPD.

Based on the evidence, we found that the burden of undiagnosed COPD in CVD remains high in the non-western regions of the world. Not surprisingly, $23 \%$ of patients with CVD have been shown to have spirometry-confirmed COPD in India ${ }^{3}$. In the middle east, $91.5 \%$ of patients with IHD with COPD were not previously diagnosed with $\mathrm{COPD}^{4}$. The results highlight the importance of active screening for COPD in CVD patients in these regions because of the potential to reduce long-term healthcare costs and morbidity amidst the resource constraints and predominance of risk factors for COPD and CVD progression.

\section{Authors' Contributions}

Conceptualization: Deshmukh K, Khanna A. Methodology: Deshmukh K, Khanna A. Data curation: Deshmukh K, Khanna A. Investigation: Deshmukh K, Khanna A. Writing original draft preparation: Deshmukh K, Khanna A. Writing review and editing: Deshmukh K, Khanna A. Approval of final manuscript: all authors. 
Table 1. Prevalence of COPD in HF registries outside of Europe and the United States

\begin{tabular}{|c|c|c|c|c|c|}
\hline Study & $\begin{array}{l}\text { Prevalence of } \\
\text { COPD in the } \\
\text { study (\%) }\end{array}$ & $\begin{array}{l}\text { Prevalence of COPD } \\
\text { in general population } \\
\text { by spirometry }(\%)\end{array}$ & $\begin{array}{l}\text { Method of COPD } \\
\text { diagnosis }\end{array}$ & Country & Region \\
\hline CONAREC-19995 & 16.10 & $14.5^{6}$ & $\begin{array}{l}\text { History and/or clinical } \\
\text { examination }\end{array}$ & Argentina & $\begin{array}{l}\text { South } \\
\text { America }\end{array}$ \\
\hline IC-SAC- $2002^{5}$ & 19 & & & Argentina & \\
\hline IC-SAC- $2004^{5}$ & 13.80 & & & Argentina & \\
\hline CONAREC- $2004^{5}$ & 13.80 & & & Argentina & \\
\hline Barretto et al. $^{2}$ & 3.85 & $15.8^{7}$ & & Brazil & \\
\hline Niteroi Study ${ }^{8}$ & 23 & & & Brazil & \\
\hline $\begin{array}{l}\text { INTER-CHF - South } \\
\text { America }^{9}\end{array}$ & 10 & & & $\begin{array}{l}\text { Argentina, Chile, } \\
\text { Colombia, and Ecuador }\end{array}$ & \\
\hline Yoshihisa et al. ${ }^{10}$ & 28 & $8.6^{11}$ & Spirometry & Japan & Asia \\
\hline Onishi et al. ${ }^{12}$ & 27 & & Spirometry & Japan & \\
\hline JASPER HHF $^{13}$ & 7.70 & & Medical records & Japan & \\
\hline KorAHF $^{14}$ & 11 & $13.4^{15}$ & Clinical and/or history & Korea & \\
\hline China PEACE $^{16}$ & 30.40 & $13.6^{17}$ & & China & \\
\hline INTER-CHF - China ${ }^{9}$ & 8 & & & China & \\
\hline HERO $\mathrm{HF}^{18}$ & 9.50 & & & China & \\
\hline $\begin{array}{l}\text { Trivandrum Heart } \\
\text { Failure registry }\end{array}$ & 15.40 & $4.2^{20}$ & & India & \\
\hline INTER_CHF India $^{9}$ & 16 & & & India & \\
\hline $\begin{array}{l}\text { INTER_CHF_Malaysia } \\
\text { and Philipines }^{9}\end{array}$ & 4 & & & Malaysia and Philippines & \\
\hline INTER-CHF Middle east $^{9}$ & 4 & & & $\begin{array}{l}\text { Egypt, Qatar, and Saudi } \\
\text { Arabia }\end{array}$ & Middle East \\
\hline Alhabeeb et al. ${ }^{21}$ & 19.70 & $4.2^{22}$ & & Saudi Arabia & \\
\hline INTERCHF Africa $^{9}$ & 2 & & & $\begin{array}{l}\text { Mozambique, Nigeria, } \\
\text { South Africa, Sudan, and } \\
\text { Uganda }\end{array}$ & Africa \\
\hline
\end{tabular}

COPD: chronic obstructive pulmonary disease; HF: heart failure.

\section{Conflicts of Interest}

No potential conflict of interest relevant to this article was reported.

\section{References}

1. Deshmukh K, Khanna A. Implications of managing chronic obstructive pulmonary disease in cardiovascular diseases. Tuberc Respir Dis 2021;84:35-45.

2. Barretto AC, Nobre MR, Wajngarten M, Canesin MF, Ballas D, Serro-Azul JB. Heart failure at a large tertiary hospital of Sao Paulo. Arq Bras Cardiol 1998;71:15-20.

3. Muralimohan BV, Ekbote G, Tousheed SZ, Ramanjenaya
R. Prevalence of COPD in vascular diseases. Eur Respir J 2015;46:PA1131.

4. Khassawneh BY, Samrah SM, Jarrah MI, Ibdah RK, Ibnian AM, Almistarehi AW, et al. Prevalence of undiagnosed COPD in male patients with coronary artery disease: a cross-sectional study in Jordan. Int J Chron Obstruct Pulmon Dis 2018;13: 2759-66.

5. Perna ER, Barbagelata A, Grinfeld L, Garcia Ben M, Cimbaro Canella JP, Bayol PA, et al. Overview of acute decompensated heart failure in Argentina: lessons learned from 5 registries during the last decade. Am Heart J 2006;151:84-91.

6. Echazarreta AL, Arias SJ, Del Olmo R, Giugno ER, Colodenco FD, Arce SC, et al. Prevalence of COPD in 6 urban clusters in Argentina: the EPOC.AR study. Arch Bronconeumol 2018;54: 260-9. 
Table 2. Prevalence of COPD in IHD/AF registries outside of Europe and the United States

\begin{tabular}{|c|c|c|c|c|}
\hline & $\begin{array}{c}\text { Prevalence of COPD } \\
\text { in the study (\%) }\end{array}$ & $\begin{array}{c}\text { Method of } \\
\text { COPD diagnosis }\end{array}$ & Country & Region \\
\hline \multicolumn{5}{|l|}{ IHD } \\
\hline Gagliardi et al. ${ }^{23}$ & 3.9 & $\begin{array}{l}\text { Medical records/clinical } \\
\text { examination/history }\end{array}$ & Argentina & South America \\
\hline Garcia Aurelio et al. $^{24}$ & 6 & & Argentina & \\
\hline Korea AMI Registry ${ }^{25}$ & 2.1 & & Korea & Asia \\
\hline $\begin{array}{l}\text { National Health } \\
\text { Insurance database }{ }^{26}\end{array}$ & 28.3 & & Taiwan & \\
\hline Das et al. ${ }^{27}$ & 52 & Spirometry & India & \\
\hline Mahendra et al. ${ }^{28}$ & 11 & & India & \\
\hline Jayamani and Chopra $^{29}$ & 11.5 & & India & \\
\hline Khassawneh et al. ${ }^{4}$ & 15.7 & & Jordan & $\begin{array}{l}\text { Middle East and } \\
\text { Africa }\end{array}$ \\
\hline GULF RACE $^{30}$ & 5.3 & Medical records & $\begin{array}{l}\text { Bahrain, Kuwait, Qatar, Oman, } \\
\text { United Arab Emirates, and } \\
\text { Yemen }\end{array}$ & \\
\hline Ibnian et al. $^{31}$ & 12.4 & Spirometry & Jordan & \\
\hline Yangui et al. ${ }^{32}$ & 20.5 & & Tunisia & \\
\hline \multicolumn{5}{|l|}{$\mathrm{AF}$} \\
\hline Albina et al. ${ }^{33}$ & 7.7 & $\begin{array}{l}\text { Medical records/clinical } \\
\text { examination/history }\end{array}$ & Argentina & South America \\
\hline Yang et al. ${ }^{34,35}$ & 11.7 & Spirometry & China & Asia \\
\hline JCARE-CARD $^{36}$ & 6.2 & $\begin{array}{l}\text { Medical records/clinical } \\
\text { examination/history }\end{array}$ & Japan & \\
\hline IHRS-AF $^{37}$ & 7.8 & & India & \\
\hline GULF SAFE $^{38}$ & 5.3 & & $\begin{array}{l}\text { Bahrain, Kuwait, Qatar, Oman, } \\
\text { United Arab Emirates, and } \\
\text { Yemen }\end{array}$ & Middle East \\
\hline
\end{tabular}

COPD: chronic obstructive pulmonary disease; IHD: ischemic heart disease; AF: atrial fibrillation.

7. Menezes AM, Jardim JR, Perez-Padilla R, Camelier A, Rosa F, Nascimento O, et al. Prevalence of chronic obstructive pulmonary disease and associated factors: the PLATINO Study in Sao Paulo, Brazil. Cad Saude Publica 2005;21:1565-73.

8. Tavares LR, Victer H, Linhares JM, de Barros CM, Oliveira MV, Pacheco LC, et al. Epidemiology of decompensated heart failure in the city of Niteroi: EPICA - Niteroi Project. Arq Bras Cardiol 2004;82:125-8.

9. Dokainish H, Teo K, Zhu J, Roy A, AlHabib KF, ElSayed A, et al. Global mortality variations in patients with heart failure: results from the International Congestive Heart Failure (INTER-CHF) prospective cohort study. Lancet Glob Health 2017;5:e665-72.

10. Yoshihisa A, Takiguchi M, Shimizu T, Nakamura Y, Yamauchi $\mathrm{H}$, Iwaya $\mathrm{S}$, et al. Cardiovascular function and prognosis of patients with heart failure coexistent with chronic obstructive pulmonary disease. J Cardiol 2014;64:256-64.
11. Minakata Y, Ichinose M. Epidemiology of COPD in Japan. Nihon Rinsho 2011;69:1721-6.

12. Onishi K, Yoshimoto D, Hagan GW, Jones PW. Prevalence of airflow limitation in outpatients with cardiovascular diseases in Japan. Int J Chron Obstruct Pulmon Dis 2014;9:563-8.

13. Sato Y, Yoshihisa A, Oikawa M, Nagai T, Yoshikawa T, Saito Y, et al. Prognostic impact of chronic obstructive pulmonary disease on adverse prognosis in hospitalized heart failure patients with preserved ejection fraction: a report from the JASPER registry. J Cardiol 2019;73:459-65.

14. Lee SE, Cho HJ, Lee HY, Yang HM, Choi JO, Jeon ES, et al. A multicentre cohort study of acute heart failure syndromes in Korea: rationale, design, and interim observations of the Korean Acute Heart Failure (KorAHF) registry. Eur J Heart Fail 2014;16:700-8.

15. Yoo KH, Kim YS, Sheen SS, Park JH, Hwang YI, Kim SH, et al. Prevalence of chronic obstructive pulmonary disease in Ko- 
rea: the fourth Korean National Health and Nutrition Examination Survey, 2008. Respirology 2011;16:659-65.

16. Yu Y, Gupta A, Wu C, Masoudi FA, Du X, Zhang J, et al. Characteristics, management, and outcomes of patients hospitalized for heart failure in China: the China PEACE Retrospective Heart Failure Study. J Am Heart Assoc 2019;8:e12884.

17. Fang L, Gao P, Bao H, Tang X, Wang B, Feng Y, et al. Chronic obstructive pulmonary disease in China: a nationwide prevalence study. Lancet Respir Med 2018;6:421-30.

18. Li L, Liu R, Jiang C, Du X, Huffman MD, Lam CSP, et al. Assessing the evidence-practice gap for heart failure in China: the Heart Failure Registry of Patient Outcomes (HERO) study design and baseline characteristics. Eur J Heart Fail 2020;22: 646-60.

19. Sanjay G, Jeemon P, Agarwal A, Viswanathan S, Sreedharan M, Vijayaraghavan G, et al. In-hospital and three-year outcomes of heart failure patients in South India: the Trivandrum Heart Failure Registry. J Card Fail 2018;24:842-8.

20. India State-Level Disease Burden Initiative CRD Collaborators. The burden of chronic respiratory diseases and their heterogeneity across the states of India: the Global Burden of Disease Study 1990-2016. Lancet Glob Health 2018;6:e136374.

21. Alhabeeb W, Elasfar A, AlBackr H, AlShaer F, Almasood A, Alfaleh $\mathrm{H}$, et al. Clinical characteristics, management and outcomes of patients with chronic heart failure: results from the heart function assessment registry trial in Saudi Arabia (HEARTS-chronic). Int J Cardiol 2017;235:94-9.

22. Al Ghobain M, Alhamad EH, Alorainy HS, Al Kassimi F, Lababidi H, Al-Hajjaj MS. The prevalence of chronic obstructive pulmonary disease in Riyadh, Saudi Arabia: a BOLD study. Int J Tuberc Lung Dis 2015;19:1252-7.

23. Gagliardi JA, Charask A, Perna E, D'Imperio H, Bono J, Castillo Costa Y, et al. National survey of ST-segment elevation acute myocardial infarction in Argentina (ARGEN-IAMST). Rev Argent Cardiol 2016;84:524-33.

24. Garcia Aurelio M, Cohen Arazi H, Higa C, Gomez Santa Maria HR, Mauro VM, Fernandez H, et al. Acute myocardial infarction with persistent ST-segment elevation: SCAR (acute coronary syndromes in Argentina) multicenter registry from the Argentine Society of Cardiology. Rev Argent Cardiol 2014;82:275-84.

25. Lee JH, Park HS, Chae SC, Cho Y, Yang DH, Jeong MH, et al. Predictors of six-month major adverse cardiac events in 30day survivors after acute myocardial infarction (from the Korea Acute Myocardial Infarction Registry). Am J Cardiol 2009; 104:182-9.

26. Su TH, Chang SH, Chen PC, Chan YL. Temporal trends in treatment and outcomes of acute myocardial infarction in patients with chronic obstructive pulmonary disease: a na- tionwide population-based observational study. J Am Heart Assoc 2017;6:e004525.

27. Das S, Mukherjee S, Kundu S, Mukherjee D, Ghoshal AG, Paul D. Presence and severity of COPD among patients attending cardiology OPD of a tertiary healthcare centre. J Indian Med Assoc 2010;108:406-9.

28. Mahendra M, S SK, Desai N, Bs J, Pa M. Evaluation for airway obstruction in adult patients with stable ischemic heart disease. Indian Heart J 2018;70:266-71.

29. Jayamani M, Chopra RK. Prevalence of undiagnosed chronic obstructive pulmonary disease (COPD) in stable ischemic heart disease patients attending a cardiac clinic. Am J Respir Crit Care Med 2020;201:A5108.

30. Hadi HA, Zubaid M, Al Mahmeed W, El-Menyar AA, Ridha M, Alsheikh-Ali AA, et al. Prevalence and prognosis of chronic obstructive pulmonary disease among 8167 Middle Eastern patients with acute coronary syndrome. Clin Cardiol 2010;33: 228-35.

31. Ibnian AM, Al-Mistarehi AH, Zghayer AA, Abuqudairi SI, Samrah SM, Jarrah MI, et al. Undiagnosed chronic obstructive pulmonary disease in patients undergoing cardiac catheterization. Am J Respir Crit Care Med 2018;197:A5061.

32. Yangui F, Touil A, Antit S, Zakhama L, Youssef SB, Charfi MR. Prevalence of lung function abnormalities in smokers with ischemic heart disease. Eur Respir J 2019;54:PA2667.

33. Albina G, De Luca J, Conde D, Giniger A. Atrial fibrillation: an observational study with outpatients. Pacing Clin Electrophysiol 2014;37:1485-91.

34. Yang YM, Shao XH, Zhu J, Zhang H, Liu Y, Gao X, et al. Risk factors and incidence of stroke and MACE in Chinese atrial fibrillation patients presenting to emergency departments: a national wide database analysis. Int J Cardiol 2014;173:242-7.

35. Huang B, Yang Y, Zhu J, Liang Y, Zhang H, Tian L, et al. Clinical characteristics and prognostic significance of chronic obstructive pulmonary disease in patients with atrial fibrillation: results from a multicenter atrial fibrillation registry study. J Am Med Dir Assoc 2014;15:576-81.

36. Hamaguchi S, Yokoshiki H, Kinugawa S, Tsuchihashi-Makaya M, Yokota T, Takeshita A, et al. Effects of atrial fibrillation on long-term outcomes in patients hospitalized for heart failure in Japan: a report from the Japanese Cardiac Registry of Heart Failure in Cardiology (JCARE-CARD). Circ J 2009;73:2084-90.

37. Vora A, Kapoor A, Nair M, Lokhandwala Y, Narsimhan C, Ravikishore AG, et al. Clinical presentation, management, and outcomes in the Indian Heart Rhythm Society-Atrial Fibrillation (IHRS-AF) registry. Indian Heart J 2017;69:43-7.

38. Domek M, Li YG, Gumprecht J, Asaad N, Rashed W, AlsheikhAli A, et al. One-year all-cause mortality risk among atrial fibrillation patients in Middle East with and without diabetes: the Gulf SAFE registry. Int J Cardiol 2020;302:47-52. 